\title{
The Value of Student Engagement for Higher Education Quality Assurance. Moving Away from the Regulatory Approach
}

\author{
El Valor del Compromiso del Estudiante para la Garantía de \\ Calidad de la Educación Superior. Alejándose del Enfoque \\ Regulatorio
}

\author{
Ruth Vilà * \\ Assumpta Aneas \\ María José Rubio \\ Montserrat Freixa
}

University of Barcelona, Spain

\begin{abstract}
There is a lack of research into quality in the practicum, despite widespread acknowledgement of its value in graduate training. This paper look for a) to determine the quality of the practicum placements where students from Pedagogy Degree performed their practicum; b) to investigate the relationships between the students' and teachers' views and the Regulatory Model criteria; and 3) to identify Regulatory Model indicators that may be associated with participants' views on the quality of practicum centres. Data was collected in two surveys, the sample comprising 106 students, 15 tutors and 291 practicum centres. The results shown that the three actors held positive views of its quality, there is a correlation between the tutors' views and the Regulatory Model, and there are two main variables related to the placement centre quality: type of practices and coverage of competences. This paper highlight the social value of students' engagement in conceptualization of quality and its indicators, going beyond the passive approach, which deals only with client satisfaction.
\end{abstract}

Keywords: Teacher education; Trainees; Educational quality; Assessment; Student participation.

Existe una falta de investigación sobre la calidad del Practicum, a pesar del reconocimiento de su valor en la formación de graduados. Este artículo busca a) determinar la calidad de los centros de Practicum del Grado de Pedagogía de la Universidad de Barcelona; b) investigar las relaciones entre los puntos de vista de los estudiantes y los tutores y los criterios del Modelo Regulatorio; y 3) identificar los indicadores del Modelo regulatorio que pueden estar asociados con las opiniones de los participantes sobre la calidad de los centros de prácticas. Los datos se recopilaron mediante dos encuestas, la muestra comprendía 106 estudiantes, 15 tutores y 291 centros de prácticas. Los resultados indican que los tres actores tienen puntos de vista positivos sobre su calidad, que existe una correlación positiva entre los puntos de vista de los tutores y el Modelo regulatorio y se identificaron dos variables relacionadas con la calidad del centro de prácticas: el tipo de prácticas y la cobertura de competencias. Este artículo destaca el valor social de la participación de los estudiantes en la conceptualización de la calidad y sus indicadores, yendo más allá del enfoque pasivo, que trata sólo la satisfacción del cliente.

Descriptores: Formación de docentes; Estudiante de prácticas; Calidad de la educación; Evaluación; Participación estudiantil.

*Contacto: ruth_vila@ub.edu

ISSN: $1696-4713$

www.rinace.net/reice/

revistas.uam.es/reice
Recibido: $\quad 15$ de noviembre 2018

$1^{\text {a }}$ Evaluación: 29 de febrero 2019

$2^{\text {a }}$ Evaluación: 10 de marzo 2019

Aceptado: $\quad 16$ de marzo 2019 


\section{Introduction}

There is plentiful literature studying the normative or regulatory aspects of quality variables and assessment and accreditation systems in higher education. This contrast starkly, however, with the lack of research into quality in the practicum, despite widespread acknowledgement of its value in graduate training (Bay 2006; Martin, \& Leberman, 2005; Ryan, Toohey, \& Hughes, 1996) and its significant impact on future employability (Gamboa, Paixão, \& De Jesús, 2013).

Most studies of the quality of the practicum have concentrated on its organization and/or its pedagogical design (Cole, Kolko, \& Craddick, 1981; Keogh, Dole, \& Hudson, 2006; Lam, \& Ching, 2007; Murphy, \& Kaffenberger, 2007; True, 2002, amongst others). We were unable to find references in the literature to placement centre quality, apart from the study by Freixa, Vilà, \& Rubio (2015) despite the crucial role played by these centres in students' learning, and, therefore, in the achievement of the university's educational goals. This is implicitly recognized in the literature when it states that the development of competences depends on the conditions and possibilities of their being put into practice (Vázquez, 2001). Thus, the practicum is the most realistic and natural context in which students can apply the competences taught on their degrees; and it is for this reason that the assessment of placement centre quality is so important. The success of the practicum, in terms of students' learning, depends to a large extent on the quality of the centre and its ability to offer students an organized environment in which to carry out the functions and activities proper to their degree, along with the resources they need and appropriate guidance and supervision, thereby enabling them to learn from their practice.

The Spanish National Agency for Quality Assessment and Accreditation (ANECA, 2008) and the Catalan Universities Quality Assurance Agency give only generic indications for teaching internships and are vague on the quality criteria for the placement centres. They do not include specific dimensions or any measurement instrument for the actors involved in the practice. It is in this general context and in particular in the Faculty of Education of the University of Barcelona where the research that is presented is located. In several versions of Quality Assurance of Practice Learning developed for the social work professions involve four types of questionnaires: for the students, for the university, for centre tutors and for the placement centres. In a first phase, the Education Placement Center Quality Regulation Model (MCP) was developed to assess the quality of three practice courses: Pedagogy, Social Work and Social Education. Pedagogy degree developed questionnaires of satisfaction of the practices directed to the students that finalized their practices and to the tutors of the Faculty. Thus, the quality of Practices was approached from a more normative aspect with the CCM and one from the satisfaction of the students. In this sense, both national (Peréz, \& Burguera, 2011) and international research (Ralph et al., 2007) indicate that students value Practices as the most significant part of their training as educational professionals.

The overall objective of this study was to analyze the Placement Centre Quality Regulation Model for the Pedagogy Degree at the University of Barcelona, taking into account the following specific objectives:

- To determine the quality of the Pedagogy degree placement centres according to the UB Education Faculty regulatory model and according to the views of the students and teachers on the degree. 
- To verify whether there are any relationships between the views of Pedagogy Degree practicum participants (UB students and tutors) on the quality of centres and the regulatory perspective of the Education Faculty Quality regulation model.

- To identify factors in the Education Faculty Practicum Quality Model that may be associated with participants' views on placement centre quality.

\section{The university of Barcelona pedagogy practicum}

In order to gain a better understanding of the University of Barcelona Pedagogy Degree Practicum, below we outline the professional profile of the degree and some of the outstanding features of the program.

The External Practice module, in which students undertake the Practicum, includes a total of 18 European Credit Transfer and Accumulation System (ECTS) organized into three study areas: individual assignments (150 hours), the practice community (consisting of the students' group and their tutor, 75 hours), and a period of immersion at a centre (225 hours). In each of these three areas students engage in a series of activities and learning situations giving them the opportunity to apply most of the competences studied on the degree, and particularly the competences included in the module (Vilà, \& Aneas, 2013), as table 1 shows.

Table 1. General and specific competences in external practice on the UB pedagogy degree

\begin{tabular}{ll}
\hline OVERARCHING COMPETENCES & \multicolumn{1}{c}{ SPECIFIC COMPETENCES } \\
\hline Ethical commitment & Communicating educational knowledge to different \\
Learning and responsibility & audiences \\
Teamwork & Analysing pedagogical needs and making educational \\
Creativity and initiative & assessments \\
Sustainability & Working with educational data and information \\
Communication & Leading educational groups and relationships \\
Applying pedagogical & Designing, implementing and assessing programmes \\
knowledge & Designing and applying learning-teaching strategies in \\
Self-awareness for personal and & varying educational and training contexts \\
professional development & Understanding the teaching-learning processes \\
Awareness of complexity & Education research \\
Problem-solving in education & Educational analysis \\
from a complex and & Embracing diversity \\
multicultural perspective & Mediating and advising \\
Innovation & Design, implementation, consultation and assessment for \\
Adaptation to change in a & training programmes, projects, initiatives and products in \\
knowledge-based society. & organizations \\
& Analysis, design, management, use and assessment of \\
& information and communication technologies in \\
& educational and training settings, both virtual and \\
& physical, including the creation of multimode and multi- \\
& alphabet resources. \\
\hline Source: Developed by the authors. & Trainer training \\
&
\end{tabular}

Source: Developed by the authors. 
The University of Barcelona Pedagogy Degree graduate is defined as an education professional who can work in varying environments in which direct and indirect educational phenomena are found (Millan et al., 2013). Her/his training equips her/him to carry out the following functions: a) interpreting the changes and trends stemming from the information society in educational/training settings; b) designing, implementing and assessing educational/training programmes, projects, and resources adapted to the needs of individuals, groups, and organizations in differing contexts; c) managing pedagogical programmes, products and resources; d) creating educational/training services and resources adapted to groups, including information technologies; e) carrying out research and applying critical thinking to current studies; and f) acting as a consultant in education/training.

The professional tasks involved in the profile may be: a) working with different groups (children, young people, senior citizens, specific groups, unemployed people, working people, amongst others); b) working in organizations that differ in size, activity (service sector, museums, consulting, schools, companies) and type (public, private); and c) specializing in specific subjects (digital learning environments, mediation, careers advice, cultural promotion, amongst others).

The systems and fields where the graduate can work when undertaking the practicum are:

- The formal education system: in this context, the pedagogue may for example impart regulated programmes, offer support in formal education, or take charge of specific regulated programmes.

- The social field: here the pedagogue can perform work such as boosting social and labour integration, promoting social cohesion, or fostering people's welfare.

- The business field: in this area, the pedagogue can work in human resources, cultural management, or developing educational/training resources.

These fields afford environments with varying degrees of formalization, complexity and structure, which can offer work settings ranging from those with wide autonomy and creativity (such as some business contexts, for example a consultancy in virtual education environments) to those which are more tightly specified and regulated (such as some formal organizations, for example a pedagogical consulting team).

The University of Barcelona Pedagogy Practicum adopts an immersion approach which specifically encourages both autonomy and integration into the placement centre (Zabalza, 1998; Ventura, 2005). The module is organized around the Reflective Practice Seminars (RPS, SPR in Catalan) in which the Practice Community meets (Wenger, 2001). Each Community is made up of a group of students carrying out their practicum in various types of centres and under the supervision of their tutor at the UB. In the RPS, based on Eraut's (2000) non-formal learning principles and the R5 Reflective Practice Model (Domingo, \& Gómez, 2014), a series of individual and group activities are carried out in order to develop awareness, reframing and articulation, thereby making explicit the implicit non-formal learning acquired in the centre. Another methodological dimension of the Community is problem-centred learning (ABP in catalan, Bueno, \& Fitzgerald, 2004). As we can see, the design of the module aims to help students develop, amongst other things, critical thinking skills, which have been validated by various studies (Aneas, \& Vilà, 2015; Vilà, \& Aneas, 2013; Vilà, Aneas, \& Rajadell, 2015). 


\section{The education faculty placement centre quality regulation model (MCP)}

The quality of placement centres for Education Faculty ${ }^{1}$ degrees at the University of Barcelona began to be researched in 2011. The study in question aimed to identify and evaluate a series of indicators for centres involved in the Faculty's practicums on the Pedagogy, Social Education and Social Work degrees. Each of these practicums draws on a list of organizations where students can carry out practice placements, and many of these are shared, accepting students from all three degree courses. From the quality assurance point of view, it was important to identify indicators which would embrace the specific features of each degree, since each has its own educational and organizational model. At the same time, the indicators needed to provide a coherent and comprehensive framework for quality assessment. The study vindicated the seven indicators that form the basis of the Faculty of Education Placement Centre Quality Regulation Model (MCP: Freixa, Vilà, \& Rubio, 2015), with their corresponding sub-dimensions and relative weighting in the final assessment. The development of this model was based on three elements: the theoretical indicators, the official documents on the practicum, and the group of researchers made up of ten tutors, one quality management expert and the ViceDean, representing the Practicum Commission).

Once the criteria or indicators had been identified, the group of researchers define the degree of importance and value of each indicator. This process was carried out in two stages (Freixa, Vilà, \& Rubio, 2015):

- In the first stage, the experts assessed the importance of the quality indicators (not very important, important, very important), and used the Kappa coefficient to estimate the degree of agreement between them.

- In the second stage, the experts assigned a numerical score to each indicator, depending on whether it was present or absent at the centre. The final score for each indicator was the average of the scores given by the experts.

Depending on the responses to the questionnaire, each centre was given a final score for the quality of its placements. Table 2 shows the details of the regulatory model indicators.

These placement centres display different features from those on the Social Work and Social Education degrees (Freixa, Vilà, \& Rubio, 2015), as the study of the quality indicators found. These features are:

- A lower ratio of students to tutors in the Pedagogy placement centre. The average number of students carrying out the practicum in the last year of this course was 200 , taking the practicum in an average of 120 centres. Thus, most centres only offered a single placement, the institutions mostly arguing that this number enabled the student to be better integrated in the organization, both in terms of material resources and attention to the trainee. Another feature of these centres is that they had a greater number of tutors with tenure.

\footnotetext{
${ }^{1}$ The University of Barcelona Pedagogy Degree is taken at the Faculty of Education, formed in 2014 when the Pedagogy and Teacher Training Faculties merged.
} 
- Greater autonomy on the Pedagogy practicum, with the exception of some organizations belonging to the Catalan Government Education Department's Educational Services, where participant observation is the prevailing practicum mode.

- The Pedagogy degree has a greater number of competences than the other two degrees, primarily developing the specific competences.

- Compared to the Social Education and Social Work degrees, there was a lower percentage of tutors qualified in Pedagogy. Tutors' qualifications were from a wide range of socio-educational backgrounds, consistent with the diversity of the organizations in which external practice is carried out.

Table 2. Quality indicators of the Regulatory Model (MCP)

Indicator 1. Extent to which the training activity is taken into consideration within the centre's activities. This quality indicator assesses three aspects: the induction of placement students, whether a placement plan is included in the centre's education project (or similar document), and whether the functions of the placement student are specified in this document.

Indicator 2. Ratio between centre tutors and placement students This indicator includes two aspects: the number of permanent placement tutors at the centres and the tutorstudent ratio for mentoring.

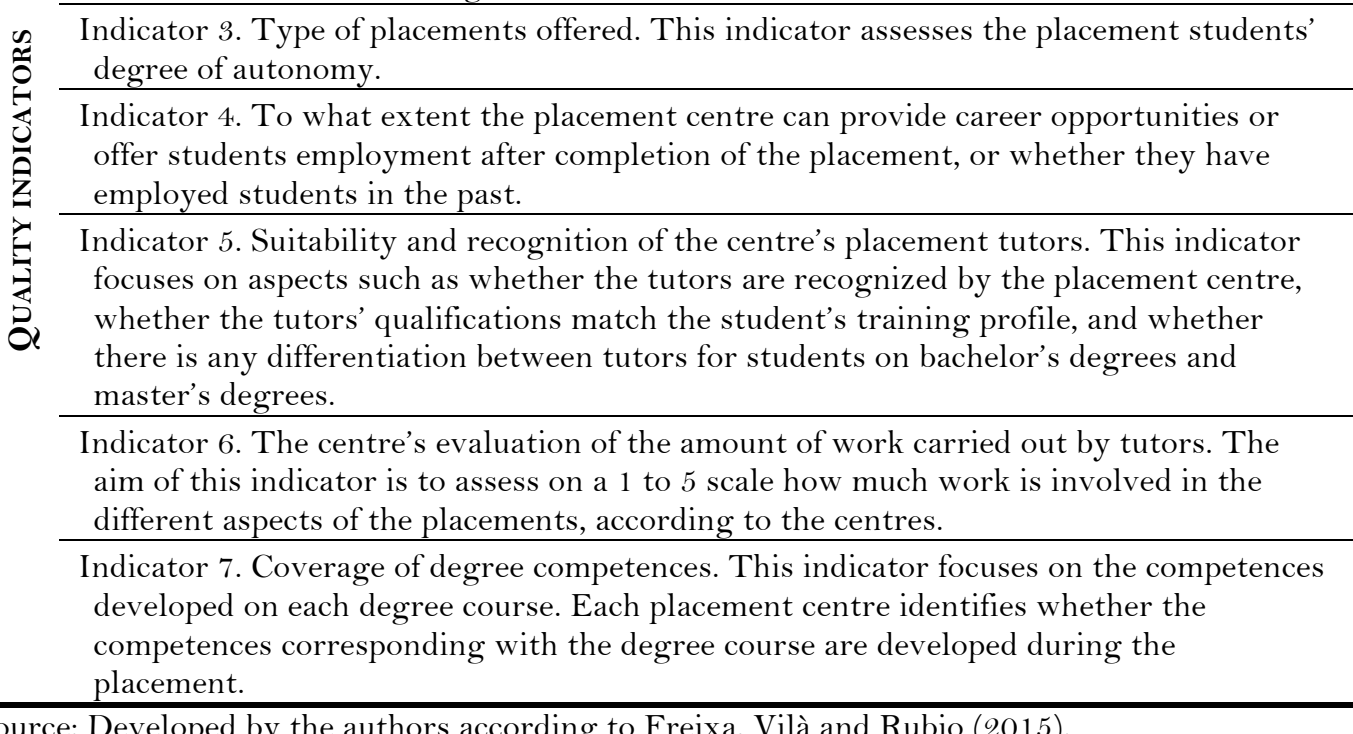
Source: Developed by the authors according to Freixa, Vilà and Rubio (2015).

\section{Method}

To address the objectives and purposes of the study we chose to survey students and tutors, and in relation to the Pedagogy Placement Centre Quality Model (MCP). The study was carried out during the 2015-2016 academic year.

\section{Participants}

Three types of population were included in the study, categorized according to the information which each could contribute. Firstly, individual perceptions of quality offered by UB students and tutors, and secondly, placement centre assessments obtained from the Placement Centre Quality Scale (Freixa, Vilà, \& Rubio, 2015). 
The Pedagogy degree student population in the 2012-13 academic year was made up of the 198 students enrolled on the final year of the course. The final sample was composed of 106 students who responded voluntarily to the questionnaire, representing a $53 \%$ response rate. The UB tutor population comprised the Practicum teaching staff, a total of 18. The definitive sample of tutors was composed of those who responded voluntarily to the questionnaire, a total of 15 , representing a response rate of $83 \%$.

The population of placement centres collaborating with the Pedagogy degree was made up of the 150 centres involved in the 2012-13 course. The final sample was composed of 106 centres, representing a response rate of $71 \%$. The centres had a wide range of types and professional fields. $50 \%$ were private, while $39 \%$ belonged to the formal education field, $28 \%$ to the social field and $13 \%$ to the business field, there being also $20 \%$ which included various fields due to their size or complexity (Barcelona City Council, for example).

\section{Instruments}

In order to assess e quality of the practicum centres on the Pedagogy degree in accordance with the regulatory model of the UB Education Faculty, the Placement Centre Quality Scale was applied. This is a scale developed by the coordination of the Practicum at the Education Faculty, made up of 18 items in 7 different dimensions (Freixa, Vilà, \& Rubio, 2015), with a Cronbach alpha of $\alpha=0.704$.

In order to obtain the tutors' views on quality, the Quality Perception Survey (Vilà, \& Aneas, 2013) was applied. This is a scalar questionnaire comprising 5 items with a Cronbach alpha of $\alpha=0.944$. In order to obtain the students' views on quality, the Quality Perception Survey (Vilà, \& Aneas, 2013) was applied, a scalar questionnaire comprising 14 items with a Cronbach alpha of $\alpha=0.838$.

\section{Procedure}

Data analysis was performed using the SPSS 18 statistical programme. Firstly, the usual descriptive data was obtained, in line with nature of the data, percentages and measures of main tendencies and dispersion. Subsequently Student's t, ANOVA and chi square contrast tests were carried out in to determine significant differences between groups.

Lastly, to determine which parameters would best explain placement centre quality, a simple correlation test (Pearson's) was performed, along with a stepwise multiple regression analysis, in order to identify the main predictive variables for placement centre quality from the points of view of the UB students and tutors. Also, collinearity tests were carried out to guarantee the non-collinearity of results.

\section{Results}

\subsection{Pedagogy placement centre quality from the different points of view}

Table 3 shows the results from the scores obtained from the students and tutors from the Quality Perception Survey, in addition to the scores obtained from the Placement Centre Quality Scale according to the Education Faculty Placement Centre Quality Regulation Model (MCP).

Three main conclusions emerge from these first results: a) the subjective assessments of the students and tutors were substantially better than the assessments from the 
regulatory model; b) the students showed the highest perception of quality; c) the results from the regulatory model had significantly higher dispersion. The results of the regulatory model placement centre quality assessment are shown in table 4 .

Table 3. Theoretical and empirical scores obtained from UB students and tutors and the regulatory model

\begin{tabular}{lcrc}
\hline & $\begin{array}{c}\text { THEORETICAL } \\
\text { MAXIMUM SCORE }\end{array}$ & MEAN & $\begin{array}{c}\text { STANDARD } \\
\text { DEVIATION }\end{array}$ \\
\hline Students' quality assessment & 10 & 8.71 & 1.63 \\
Tutors' quality assessment & 10 & 7.15 & 2.17 \\
Regulatory model assessment & 100 & 58.48 & 16.30 \\
\hline
\end{tabular}

Source: Developed by the authors.

Table 4. Theoretical and empirical scores obtained from UB students and tutors and the MCP regulatory model

\begin{tabular}{lccc}
\hline & $\begin{array}{c}\text { THEORETICAL } \\
\text { MAXIMUM SCORE }\end{array}$ & MEAN & $\begin{array}{c}\text { STANDARD } \\
\text { DEVIATION }\end{array}$ \\
\hline $\begin{array}{l}\text { Consideration of training activity among all } \\
\text { other activities }\end{array}$ & 26 & 11.77 & 9.67 \\
$\begin{array}{l}\text { Relationship between the number of centre } \\
\quad \text { tutors and students }\end{array}$ & 10 & 6.24 & 4.01 \\
$\begin{array}{l}\text { Type of practice offered } \\
\text { Employment prospects at the centre }\end{array}$ & 12 & 9.08 & 2.58 \\
$\begin{array}{l}\text { Tutor suitability and recognition } \\
\text { Centre's internal assessment of tasks carried }\end{array}$ & 10 & 4.57 & 4.13 \\
$\quad$ out by centre tutors & 15 & 4.84 & 3.32 \\
Coverage of degree competences & 7 & 4.80 & 1.98 \\
\hline Total & 20 & 16.30 & 7.80 \\
\hline
\end{tabular}

Source: Developed by the authors.

Analysing this assessment of centres it can be seen that the worst-scoring factor is Indicator 5 (Suitability and recognition of the centre's placement tutors). This indicator enquires into aspects such as whether the tutors are recognized by the placement centres. Contrastingly, Indicators 3 and 7 (type of placements offered or level of independence in the placements, and coverage of degree competences) obtained the highest scores.

Turning to the relationships between the three different points of view (students, UB tutors and the MCP), a weak but significant correlation between UB tutors' assessments and those of the regulatory model can be observed. In contrast students' perceptions did not relate to either of the others; instead they had their own separate views on practicum centre quality.

\subsection{Contributions to the model of quality from the students' point of view}

Given the distinct views of placement centre quality found among the students, their concept of quality was analysed in greater depth. To achieve this, a multiple linear regression analysis was applied, in which the dependent variable is the quality assessment that students gave to the placement centres and the independent variables are the seven quality indicators of the regulatory model. The purpose was to determine which elements of the model could predict students' perceptions. 
Table 5. Correlations between participants' quality scores and those of the regulatory model

\begin{tabular}{|c|c|c|c|c|}
\hline & & $\begin{array}{c}\text { TOTAL } \\
\text { QUALITY } \\
\text { MCP } \\
\end{array}$ & $\begin{array}{c}\text { QUALITY } \\
\text { ACCORDING } \\
\text { TO STUDENTS } \\
\end{array}$ & $\begin{array}{c}\text { Total QUALITY } \\
\text { ACCORDING TO UB } \\
\text { TUTORS } \\
\end{array}$ \\
\hline \multirow{3}{*}{ Total Quality MCP } & Pearson Correlation & 1 & -0.037 & $0.357^{*}$ \\
\hline & Sig. (bilateral) & & 0.810 & 0.028 \\
\hline & $\mathrm{N}$ & 91 & 44 & 38 \\
\hline \multirow{3}{*}{$\begin{array}{l}\text { Quality according to } \\
\text { students }\end{array}$} & Pearson Correlation & -.037 & 1 & 0.332 \\
\hline & Sig. (bilateral) & 0.810 & & 0.059 \\
\hline & $\mathrm{N}$ & 44 & 45 & 33 \\
\hline \multirow{3}{*}{$\begin{array}{l}\text { Total Quality according } \\
\text { to UB tutors }\end{array}$} & Pearson Correlation & $0.357^{*}$ & 0.332 & 1 \\
\hline & Sig. (bilateral) & 0.028 & 0.059 & \\
\hline & $\mathrm{N}$ & 38 & 33 & 39 \\
\hline
\end{tabular}

Note: * The correlation is significant at the level of 0.05 (bilateral).

Source: Developed by the authors.

Table 6. Model of multiple linear regression for placement centre quality from students' perspective

\begin{tabular}{|c|c|c|c|c|c|c|c|}
\hline & \multicolumn{2}{|c|}{$\begin{array}{c}\text { NON- } \\
\text { STANDARDIZED } \\
\text { COEFFICIENTS }\end{array}$} & \multirow{2}{*}{$\begin{array}{c}\text { STANDARDIZED } \\
\text { COEFFICIENTS } \\
\text { Beta }\end{array}$} & \multirow[t]{2}{*}{$\mathbf{t}$} & \multirow{2}{*}{ SIG. } & \multicolumn{2}{|c|}{$\begin{array}{c}\text { COLLINEARITY } \\
\text { STATISTICS }\end{array}$} \\
\hline & B & $\begin{array}{l}\text { Typical } \\
\text { error }\end{array}$ & & & & Tolerance & FIV \\
\hline (Constant) & 3.871 & 0.650 & & 5.953 & 0.000 & & \\
\hline $\begin{array}{l}\text { 1. Consideration of } \\
\text { training activity } \\
\text { among all other } \\
\text { activitieso }\end{array}$ & 0.003 & 0.013 & 0.040 & 0.272 & 0.787 & 0.936 & 1.068 \\
\hline $\begin{array}{l}\text { 2. Relationship between } \\
\text { the number of centre } \\
\text { tutors and students }\end{array}$ & 0.021 & 0.034 & 0.099 & 0.618 & 0.541 & 0.767 & 1.304 \\
\hline $\begin{array}{l}\text { 3. Type of practice } \\
\text { offered }\end{array}$ & 0.135 & 0.061 & 0.497 & 2.199 & 0.035 & 0.389 & 2.573 \\
\hline $\begin{array}{l}\text { 4. Employment } \\
\text { prospects at the } \\
\text { centre }\end{array}$ & -0.058 & 0.030 & -0.299 & -1.934 & 0.061 & 0.832 & 1.202 \\
\hline $\begin{array}{l}\text { 5. Centre tutor } \\
\text { suitability and } \\
\text { recognition }\end{array}$ & 0.045 & 0.045 & 0.154 & 1.005 & 0.322 & 0.840 & 1.190 \\
\hline $\begin{array}{l}\text { 6. Centre's internal } \\
\text { assessment of tasks } \\
\text { carried out by centre } \\
\text { tutors }\end{array}$ & 0.029 & 0.066 & 0.064 & 0.439 & 0.663 & 0.949 & 1.054 \\
\hline $\begin{array}{l}\text { 7. Coverage of degree } \\
\text { competences }\end{array}$ & -0.058 & 0.023 & -0.552 & -2.503 & 0.017 & 0.408 & 2.450 \\
\hline
\end{tabular}

Note: Dependent variable: Quality according to students.

Source: Developed by the authors. 
The results show an acceptable model of regression, with $31 \%$ prediction $\left(\mathrm{R}^{2}=0.305\right)$. The assumptions of linearity, normality, independence and homoscedasticity were tested. The collinearity tests (table 6) show that there was no exact linear relationship between any of the independent variables. None of the seven quality indicators for the placement centres were excluded from the regression model. However, two indicators, 2 and 7, stood out as statistically significant.

From the students' perspective, the two quality predictors were:

- Indicator 2: Type of practice $(\mathrm{r}=0.135)$. This is the stronger predictive variable and indicates that the centres with the highest quality scores were those where students carried out autonomy-promoting practice.

- Indicator 7: Coverage of competences $(r=-0.058)$. This is less strong than the previous predictive variable and indicates that the highest rated centres for students were those where a lower number of competences were worked on; specifically, a maximum of 9 competences of the 28 featured on the Pedagogy degree.

The assessments emerging from these results are consistent with the Pedagogy Practicum model, which fosters immersion in the organizations where the highest degree of students' working autonomy is promoted.

\section{Discussion and conclusions}

Concerning the first objective of this study we can conclude that the three actors involved in the Pedagogy Practicum all had a positive view of its quality, although the students were those who rated it most highly. Concerning the second objective, a positive correlation between the views of UB tutors and the Education Faculty regulatory model was shown.

Finally, turning to the third objective, the main variables indicating placement centre quality from the students' perspective were identified. The first of these two factors were the approach promoting student autonomy, and the second marked out the centres practising the lowest number of competences (a maximum of 9). We would interpret this as showing the need to design a type of practicum in which students can concentrate their efforts on applying and developing a limited number of competences, thus favouring better results in the application of learning and in working autonomy.

This study has gone into greater depth in investigating quality management in University of Barcelona Faculty of Education placement centres: a little-researched topic, despite its strategic importance. The first stage undertook the identification and validation of placement centre quality indicators based on the regulatory approach, developed on the basis of a review of literature on quality in training systems (Freixa, Vilà, \& Rubio, 2015). The results of the second stage afford a complementary and enriched perspective on placement centre quality, featuring the views of students and tutors on the UB Pedagogy Degree Practicum.

This study is not exempt from limitations, one of which is the methodological design itself. However, this design has allowed us to introduce fear first time the vision of the different actors of the practicum. In the future, it should be complemented with their own 
voice, thus having the opportunity to deepen more in what the students and tutors live and feel during the internship.

Our study follows in a line of work, developed also by Daugherty (2011) and Crespi and Lopez (2009) amongst others, which analyses comparatively the perceptions of the various actors involved in the practicum. In our case, we found a slight correlation between the assessment of UB tutors and the regulatory assessment obtained from the scale of the MCP Model.

Also, we wished to go into further depth in one of the key debates concerning higher education quality assessment: namely the relationships between regulatory assessments and those based on the views of training programme participants. Regulatory assessments are those which validate or assure quality according to deductive and objectivized indicators, while the second type is more inductive and subjective. In our case, the authors wished to probe whether any relationship or concurrence could be found between students' assessments of placement centre quality and those obtained via a regulatory system of quality assurance, specifically the MCP. In this regard, an important conclusion of this study should be noted: i.e. that students hold their own, independent views on placement centre quality.

The literature has studied widely the value of student perceptions in higher education quality control (Bakx et al., 2015; Choudhury, 2015; Kashif, \& Ting, 2014; Mourad, 2013; Voss, Gruber, \& Szmigin, 2007; Xiao, \& Wilkins, 2015; Zamberi, 2015). This study thus complements others which have analysed quality assessment outside the educational organization itself, such as those by Stukalina (2012) and Gallifa and Batallé (2010), which also focused their attention on placement centre quality. These opinions, collected from students rather than the institutions, are more positive than those of tutors and the regulatory model.

Various questions to be addressed by future studies emerge from these results, for example: Why do these differences in assessment exist? What lies behind students' more positive assessments of placement centres? Concerning the factors in placement centre quality highlighted by the students' viewpoints, our conclusion is that they offer pointers towards an inductive quality model which would emerge from students' practice and experience. Our hypothesis is that the Pedagogy Practicum model, which fosters immersion in the organization and autonomy under the centre's supervision (Millan et al., 2014), is a key element in students' assessments. We should take account of the importance of the two predictive indicators for quality assessment that students' views marked out in the regulatory model, and the fact that both, especially the second indicator concerning the number of competences developed, are aimed at directing the graduate profile towards specialization instead of multi-functionality (the current orientation).

\section{Implications for university practice}

Various conclusions can be derived from this study. The first and most important is that students should not simply be objects of the learning process, but should become active agents in the relationship between the university and the placement centres. This conclusion bases its premises on students' technical skills and social value, amply backed up by the literature. Regarding their technical proficiency, in our view the University of Barcelona Pedagogy Degree Practicum model provides students with the competences they need to achieve this. This model enables students not only to develop and apply the 
whole set of necessary technical and social competences but also to understand the centre more globally, from its culture to its organizational structure and management model. In our view this is possible because the contents of the module provide students with the conceptual and methodological equipment required to develop a critical assessment of their workplace (the placement centre) and to be key actors in quality assessment (Aldridge, \& Rowley, 1998; Oldfield, \& Baron, 2000).

Concerning the social value of students' engagement, the current trend towards service user participation cannot be ignored; in our case, this means taking students as key actors. This role, within the engagement and partnership model, is consistent with current organizational perspectives and with the values of the society of our time (Kezar, \& Kinzie, 2006; Simons et al., 2012; Vickers, Harris, \& McCarthy, 2004). Here we would like to underline the importance of involving students in conceptualization of quality and its indicators, going beyond the passive approach which deals only with client satisfaction. Our results indicate the need to revise the Pedagogy Degree Placement Centre Quality Regulation Model in order to take students' views into account.

\section{References}

Aldridge, S., \& Rowley, J. (1998). Measuring customer satisfaction in higher education. Quality Assurance in Education, 6(4), 197-204. https://doi.org/10.1108/09684889810242182

Aneas, A., \& Vilà, R. (2015). ¿Hay cambios en la percepción que tiene el alumnado sobre su competencia tras haber desarrollado su Prácticum? El caso del practicum del grado de Pedagogía de la Universidad de Barcelona [Are there changes in the student's percepcions about their competences just finished their Practicum?]. In AIDIPE (Ed.), Investigar con y para la sociedad (pp. 1073-1084). Cádiz: AIDIPE.

Bakx, A., Koopman, M., De Kruijf, J., \& Den Brok, P. (2015). Primary school pupil's views of characteristics of good primary school teachers: An exploratory, open approach for investigating pupils' perceptions. Teachers and Teaching, 21(5), 1-22.

https://doi.org/10.1080/13540602.2014.995477

Bay, J. (2006). Preparing undergraduates for careers: An argument for the internship practicum. College English, 69(2), 134-141. https://doi.org/10.2307/25472198

Bueno, P. M., \& Fitzgerald, V. L. (2004). Problem based learning. Theoria, 13, 145-157.

Choudhury, K. (2015). Evaluating customer-perceived service quality in business management education in India. Asia Pacific Journal of Marketing and Logistics, 27(2), 208-225. https://doi.org/10.1108/APJML-04-2014-0065

Cole, M. A., Kolko, D. J., \& Craddick, R. A. (1981). The quality and process of the internship experience. Professional Psychology, 12(5), 570-577. https://doi.org/10.1037/07357028.12 .5 .570

Crespi, T. D., \& Lopez, P. G. (1999). Practicum and internship supervision in the schools: Standards and considerations for school psychology supervisors. The Clinical Supervisor, 17(2), 113-126. https://doi.org/10.1300/Jo01v17no2_07

Daugherty, E. L. (2011). The public relations internship experience: A comparison of student and site supervisor perspectives. Public Relations Review, 37(5), 470-477.

https://doi.org/10.1016/j.pubrev.2011.09.010 
De Jager, J., \& Gbadamosi, G. (2013). Predicting students' satisfaction through service quality in higher education. The International Journal of Management Education, 11, 107-1 18. https://doi.org/10.1016/j.ijme.2013.09.001

Domingo, A., \& Gómez, M.V. (2014). La práctica reflexiva. Bases, modelos e instrumentos [Reflexive practices. Bases, models and tools]. Madrid: Narcea.

Eraut, M. (2000). Non-formal learning and tacit knowledge in professional work. British Journal of Educational Psychology, 7O(1), 113-136. https://doi.org/10.1348/000709900158001

Freixa, M., Vilà, R., \& Rubio, M. J. (2015). Quality assessment for placement centres: A case study of the University of Barcelona's faculty of education. Assessment and Evaluation in Higher Education, 4O(2), 199-217. https://doi.org/10.1080/02602938.2014.898738

Gallifa, J., \& Batallé, P. (2010). Student perceptions of service quality in a multi-campus higher education system in Spain. Quality Assurance in Education, 18(2), 156-170. https://doi.org/10.1108/09684881011035367

Gamboa, V., Paixão, M. P., \& De Jesús, S. N. (2013). Internship quality predicts career exploration of high school students. Journal of Vocational Behavior, 83(1), 78-87. https://doi.org/10.1016/j.jvb.2013.02.009

Kashif, M., \& Ting, H. (2014). Service-orientation and teaching quality: Business degree students' expectations of effective teaching. Asian Education and Development Studies, 3(2), 163-180. https://doi.org/10.1108/AEDS-06-2013-0038

Keogh, J. E., Dole, S. L., \& Hudson, E. (2006). Supervisor or mentor? Questioning the quality of pre-service teacher practicum experiences. In AARE. (Ed.), Australian association for research in education 2006 international education research conference (pp. 1-15). Deakin: AARE.

Kezar, A. J., \& Kinzie, J. (2006). Examining the ways institutions create student engagement: The role of mission. Journal of College Student Development, 47(2), 149-172. https://doi.org/10.1353/csd.2006.0018

Lam, T., \& Ching, L. (2007). An exploratory study of an internship program: The case of Hong Kong students. International Journal of Hospitality Management, 26(2), 336-351. https://doi.org/10.1016/j.ijhm.2006.01.001

Martin, A. J., \& Leberman, S. I. (2005). Keeping up with the play: Practicum, partnership and practice. Asia-Pacific Journal of Cooperative Education, 6(2), 17-25.

Millan, D., Burguet, M., Vilà, R., Aneas, A., Rajadell, N., \& Noguera, E. (2014). El pràcticum al grau de pedagogia de la Universitat de Barcelona [The pedagogy degree practicum of the University of Barcelona]. Revista d'Innovació Docent $i$ Universitària, 6, 32-52.

Mourad, M. (2013). Students' perception of quality assurance activities. Sustainability, Accounting, Management and Policy Journal, 4(3), 345-365. https://doi.org/10.1 108/SAMPJ-01-20130007

Murphy, S., \& Kaffenberger, C. (2007). ASCA national model: The foundation for supervision of practicum and internship students. Professional School Counselling, 1O(3), 289-296. https://doi.org/10.5330/prsc.10.3.d4tog 103013n88t6

Oldfield, B. M., \& Baron, S. (2000). Student perceptions of service quality in a UK university business and management faculty. Quality Assurance in Education, 8(2), 85-95. https://doi.org/10.1108/09684880010325600

Pérez, J., \& Burguera, J. L. (2011). La evaluación del practicum de pedagogía en el proceso de transición de la licenciatura al grado [The evaluation of the pedagogy practicum in the 
proces of transition from the bachelor to the degree]. Revista de Docencia Universitaria, 9(2), 71-96. https://doi.org/10.4995/redu.2011.6161

Ralph, E., Walker, K., \& Wimmer, R. (2007). The practicum in professional education: Pre-service students experiencies. Tranformative Dialogues: Teaching and Learning Journal, 1(2), 1-17.

Ryan, G., Toohey, S., \& Hughes, C. (1996). The purpose, value and structure of the practicum in higher education: A literature review. Higher Education, 31(3), 355-377. https://doi.org/10.1007/BFO0128437

Simons, L., Fehr, L., Blank, N., Connell, H., Georganas, D., Fernandez, D., \& Peterson, V. (2012). Lessons learned from experiential learning: What do students learn from a practicum/internship? International Journal of Teaching and Learning in Higher Education, $24(3), 325-334$.

Stukalina, Y. (2012). Addressing service quality issues in higher education: The educational environment evaluation from the students' perspective. Technological and Economic Development of Economy, 18(1), 84-98. https://doi.org/10.3846/20294913.2012.658099

True, M. (2002). Starting and maintaining a quality internship program. Technology Council of Central Pennsylvania. Available in https://www.connectva.org/wp-content/uploads/GoalSetting-Worksheet.pdf

Vázquez, Y. A. (2001). Educación basada en competencias [Competence based assessment]. Educar: Revista de Educación/Nueva Época, 16, 1-29.

Ventura, J. (2005). El practicum en los estudios pedagógicos y la inserción laboral [The practicum at the pedagogical studies and the occupational insertion]. Doctoral thesis. Universidad de Barcelona.

Vickers, M., Harris, C., \& McCarthy, F. (2004). University-community engagement: Exploring service-learning options within the practicum. Asia-Pacific Journal of Teacher Education, 32(2), 129-141. https://doi.org/10.1080/1359866042000234223

Vilà, R., \& Aneas, A. (2013). Los seminarios de práctica reflexiva en el prácticum de pedagogía de la Universidad de Barcelona [Reflexive practice seminars at the pedagogy practicum at the University of Barcelona]. Bordón, 65(3), 165-181.

Vilà, R., Aneas, A., \& Rajadell, N. (2015). La evaluación de competencias del alumnado en las prácticas externas [Students's competences assessmtne at their intership]. Procedia-Social and Behavioral Sciences, 196(8), 226-232. https://doi.org/10.1016/j.sbspro.2015.07.034

Vilà, R., Burguet, M., Aneas, A., Rajadell, N., Noguera, E., \& Millan, D. (2014). El practicum al grau de pedagogia de la Universitat de Barcelona: El mapa de la professio, la pràctica simulada i la immersio en una organització ¿Pedagogy practicum at the University of Barcelona. Map of the profession, simulate practice and immersion]. Revista d'Innovació $i$ Recerca en Educació, 7(1), 93-112.

Voss, R., Gruber, T., \& Szmigin, I. (2007). Service quality in higher education: The role of student expectations. Journal of Business Research, 60, 949-959. https://doi.org/10.1016/j.jbusres.2007.01.020

Wenger, E. (2001). Comunidades de práctica: Aprendizaje, significado e identidad [Communities of practice: Learning, meaning and identity]. Barcelona: Paidós.

Xiao, J., \& Wilkins, S. (2015). The effects of lecturer commitment on student perceptions of teaching quality and student satisfaction in Chinese higher education. Journal of Higher Education Policy and Management, 37, 98-110.

https://doi.org/10.1080/1360080X.2014.992092 
Stukalina, Y. (2012). Addressing service quality issues in higher education: The educational environment evaluation from the students' perspective. Technological and Economic Development of Economy, 18, 84-98. https://doi.org/10.3846/20294913.2012.658099

Zabalza, M. A. (1998). El prácticum y las prácticas en empresas en la formación universitaria [The practicum and the internship in companies in the higher education]. In M. A. Zabalza \& L. Iglesias (Eds.), $V$ Symposium internacional sobre el prácticum. Innovaciones en el prácticum (pp. 7-38). Poio: Universidad de Vigo.

Zamberi, S. (2015). Evaluating student satisfaction of quality at international branch campuses. Assessment and Evaluation in Higher Education, 40, 488-507. https://doi.org/10.1080/02602938.2014.925082

\section{Brief CV of the authors}

\section{Ruth Vilà}

$\mathrm{PhD}$ in Psychopedagogy. Professor at the Faculty of Education of the University of Barcelona. He is a member of the Board of Directors of the Institute of Research in Education (IRE). He is part of the research group in Intercultural Education (GREDI) and the consolidated teaching innovation group PRAXIS on the Practicum (http://www.ub.edu/praxis/es). He has participated and coordinated research on external practices and the degree of Pedagogy. As a result of this, there are several publications: Aneas, Rubio and Vilà (2018) Digital portfolios and evaluation of crossdisciplinary competences in the external practices of the degree of Pedagogy of the University of Barcelona (Journal Educar). Vilà and Aneas (2013) The Seminars of Reflective Practice in the Practicum of Pedagogy of the University of Barcelona (Journal Bordón). Freixa, Vilà \& Rubio (2015) Quality assessment for placement centres: a case study of the University of Barcelona's (Journal Assessment \& Evaluation in Higher Education). ORCID ID: https://orcid.org/0000-0003-3768-1105. Email: ruth_vila@ub.edu

\section{Assumpta Aneas}

Teaches in Educational Research, Advice for professional and personal development and Evaluation of learning and skills. Belongs to the Department of Research Methods and Evaluation in Education. She is coordinator of the Practicum of Pedagogy. He is Head of the Equity Area, Welfare and Inclusion Area of the Institute of Research in Education of the University of Barcelona. She is also the coordinator of the GREDI Intercultural Education Research Group of the UB and the URV of Tarragona. Belongs to the PRAXIS Teacher Innovation Group of the UB Pedagogy Practicum. It has 200 publications (book chapters, articles in magazines, conferences and open access materials) in Spanish, Catalan, English and German. ORCID ID: https://orcid.org/o000-0002-9519-6696. Email: aaneas@ub.edu

\section{María José Rubio}

PhD in Pedagogy. Professor in the Faculty of Education at the University of Barcelona. Teaching in Masters, Postgraduate, Undergraduate, and degrees mainly in areas of Methodology research, ICT (Information and communication technology) and External practices of Pedagogy. She is a researcher in the research center GREAV at University of 
Barcelona (Research Group in Virtual teaching and learning). Her research and her publications includes the topics concern to: professional competences and ICT-mediated teaching and learning. ORCID ID: https://orcid.org/0000-0003-2052-7611. Email: mjrubio@ub.edu

\section{Montserrat Freixa}

$\mathrm{PhD}$ in Pedagogy from the University of Barcelona. She has held the following academic positions in the University: secretary of the MIDE Department, head of studies of Social Education and academic vice-dean of the Faculty of Pedagogy. For many years, she has been part of the coordination team of the social education practicum working on the role of the agents involved, evaluating the institutions and developing materials and resources for the three agents: student, university tutor and center tutor. Member of the research group Academic and Labour Transitions, recognized by the Generalitat de Catalunya. Her main lines of research are: family and disability, university abandonment, transitions, and religious diversity and intercultural dialogue. ORCID ID: https://orcid.org/oooooo01-9119-9868. Email: mfreixa@ub.edu 